\title{
Effects of flood regime on the diet of Triportheus curtus (Garman, 1890) in an Amazonian floodplain lake
}

\author{
Jardely de Oliveira Pereira ${ }^{1}$, Maralina Torres da Silva ${ }^{1}$, Lisandro Juno Soares Vieira ${ }^{1}$ \\ and Rosemara Fugi ${ }^{2}$
}

\begin{abstract}
We analyzed the diet of Triportheus curtus in Lake Amapá on the Acre River (AC - Brazil), during three distinct phases of the hydrological cycle (pre-flooding, flooding, and post-flooding stages). The flooding occurred between January and June of 2009. Samples were collected monthly from October 2008 through September 2009. After collection (at 19:00, 01:00, 07:00, and 13:00 hs) and taxonomic identification, fish were eviscerated and their stomachs preserved in a $4 \%$ formalin solution for later analysis. The diet was evaluated by the Index of Relative Importance (IRI), and temporal variations (pre-flooding, flooding, and post-flooding) in the diet were summarized by an ordination technique (DCA). The diet of T. curtus was comprised of several orders of insects and microcrustaceans. In the pre-flooding stage, more than $62 \%$ of the diet consisted of Ostracoda. In the flooding phase, T. curtus fed mainly on Chaoboridae larvae (Diptera) (44.3\%) and terrestrial insects (fragments) $(33.7 \%)$. In the post-flooding phase, Chaoboridae comprised $80 \%$ of the diet. These results indicate that the utilization of food resources by T. curtus was variable, changing with alterations in the availability of resources, as influenced by the hydrological cycle. The population of T. curtus proved to be opportunistic, changing its diet in the course of the hydrological cycle.
\end{abstract}

Neste estudo avaliamos a dieta de Triportheus curtus, no lago Amapá, rio Acre (AC - Brasil), em três períodos distintos do ciclo hidrológico (pré-pulso, pulso e pós-pulso). As coletas foram realizadas mensalmente de outubro de 2008 a setembro de 2009, e o pulso de cheia ocorreu entre janeiro e junho de 2009. Após as despescas (19:00, 01:00, 07:00 e 13:00 hs) e identificação taxonômica, os indivíduos foram eviscerados e os estômagos preservados em formalina $4 \%$ para posterior análise. A dieta foi avaliada através do Índice de Importância Relativa (IRI), e as variações temporais (pré-pulso, pulso e pós-pulso) na dieta foram sumarizadas através de uma análise de ordenação (DCA). A dieta de T. curtus foi composta de insetos de diferentes ordens e microcrustáceos. No pré-pulso, aproximadamente $62 \%$ da dieta foi composta por Ostracoda. No pulso, T. curtus consumiu principalmente larvas de Chaoboridae (Diptera) (44,3\%) e insetos terrestres (fragmentos) (33,7\%). No pós-pulso, larvas de Chaoboridae representaram $80 \%$ da dieta. Estes resultados indicam que a dieta de T. curtus varia temporalmente, e que a espécie pode ser considerada oportunista, alterando sua dieta de acordo com a abundância dos recursos nas diferentes fases do ciclo hidrológico.

Key words: Acre River, Feeding plasticity, Opportunist, Seasonality, Triportheinae.

\section{Introduction}

The hydrological regime, with alternating dry and flood periods, is the most important environmental factor structuring the aquatic communities and the functioning of river-floodplain systems (Sousa \& Freitas, 2008; LuzAgostinho et al., 2009; Neiff et al., 2009). The seasonal floods increase the connectivity between waterbodies, allowing exchange of nutrients and organisms among habitats (Thomaz et al., 2007).
During the floods, the riverbanks are inundated, forming habitats with distinct hydrological characteristics, resulting in differing ecological processes and diversified communities (Yamamoto et al., 2004). These factors make floodplains ideal places for reproduction, refuge, and feeding for many species of fishes (Marçal-Simabuku \& Peret, 2002; Luz et al., 2009). According to Junk (1980), changes in hydrological conditions affect not only the quantity, but also the quality of available food. In this way, the availability of food resources for ichthyofauna is related to the river dynamics, and the flooded

${ }^{1}$ Laboratório de Ictiologia e Ecologia Aquática, Centro de Ciências Biológicas e da Natureza, Universidade Federal do Acre (UFAC).

Rodovia BR 364, Km 04, Distrito Industrial, 69915-900 Rio Branco, AC, Brazil. jardelyoliveira@hotmail.com

${ }^{2}$ Programa de Pós-Graduação em Ecologia de Ambientes Aquáticos Continentais, Universidade Estadual de Maringá. 
areas play an important ecological role, benefiting the entire drainage basin (Winemiller et al., 2000).

Floodplain lakes, lentic systems formed by the main river dynamics, are important components of the river-floodplain system, which presents different degrees of connection to the main channel. Among the kinds of lakes occurring in the Amazon region are the oxbow lakes formed in abandoned meanders, which are important for the maintenance and integrity of regional biological diversity, both as natural nurseries of commercially important species of fishes, and as the preferred habitat of sedentary and small-sized species (Hamilton \& Lewis, 1987; Daga et al., 2009).

Prominent among the fishes that inhabit seasonally flooded areas in the Amazon basin are species of the genus Triportheus Cope, 1872, commonly known as sardinhas (sardines). Their adaptations allow them to exploit many biotopes, and they occur from the La Plata River to the Orinoco basins and are well represented in many rivers of Amazonia (Goulding, 1980). This group of fishes is distinguished by its economic importance, constituting a valuable food resource for traditional communities (Amaral, 2005), and several species are review in Manaus (Yamamoto et al., 2004) and Porto Velho (Doria \& Queiroz, 2008). In recent years, species of Triportheus have been one of the main targets of the commercial fishery in practically the entire Brazilian Amazon basin (Batista \& Petrere Jr., 2003). The fishery for sardinhas is seasonal, and they are harvested in the September-November period, when they migrate over long distances to breed (Doria \& Queiroz, 2008). The freshwater sardinhas of the genus Triportheus are small-sized pelagic species with a superior mouth position and weak dentition, and their usual diets includes seeds, plankton, and small invertebrates (Malabarba, 2004). Their feeding habits range from omnivore to insectivore and some species are partly zooplanktivorous, in different environments (Galina \& Hahn, 2003).

As the flooding makes available a series of food resources, transported by the river or by the flooding of its banks, the fish are able to take advantage of this situation to exploit these resources. The main objective of this study was to evaluate the effects of the flooding on the use of food resources by Triportheus curtus. Specifically, we have tried to answer the following question: does T. curtus show differences in the diet in the course of a hydrological cycle?

\section{Material and Methods}

Study area. Lake Amapá is located in the basin of the Acre River (Amazon basin) in the Municipality of Rio Branco, State of Acre, Brazil, between coordinates 1002'36"S 67'50'24' W (Fig. 1). It is a typical oxbow lake, approximately $3.1 \mathrm{~km}$ long. Its forested shores are inundated during the flood season, with consequent large input of organic matter into the lake (Keppeler \& Hardy, 2004). The lake is isolated from the river during the entire dry season, and is connected only during the flood period. The data for Acre River levels were provided

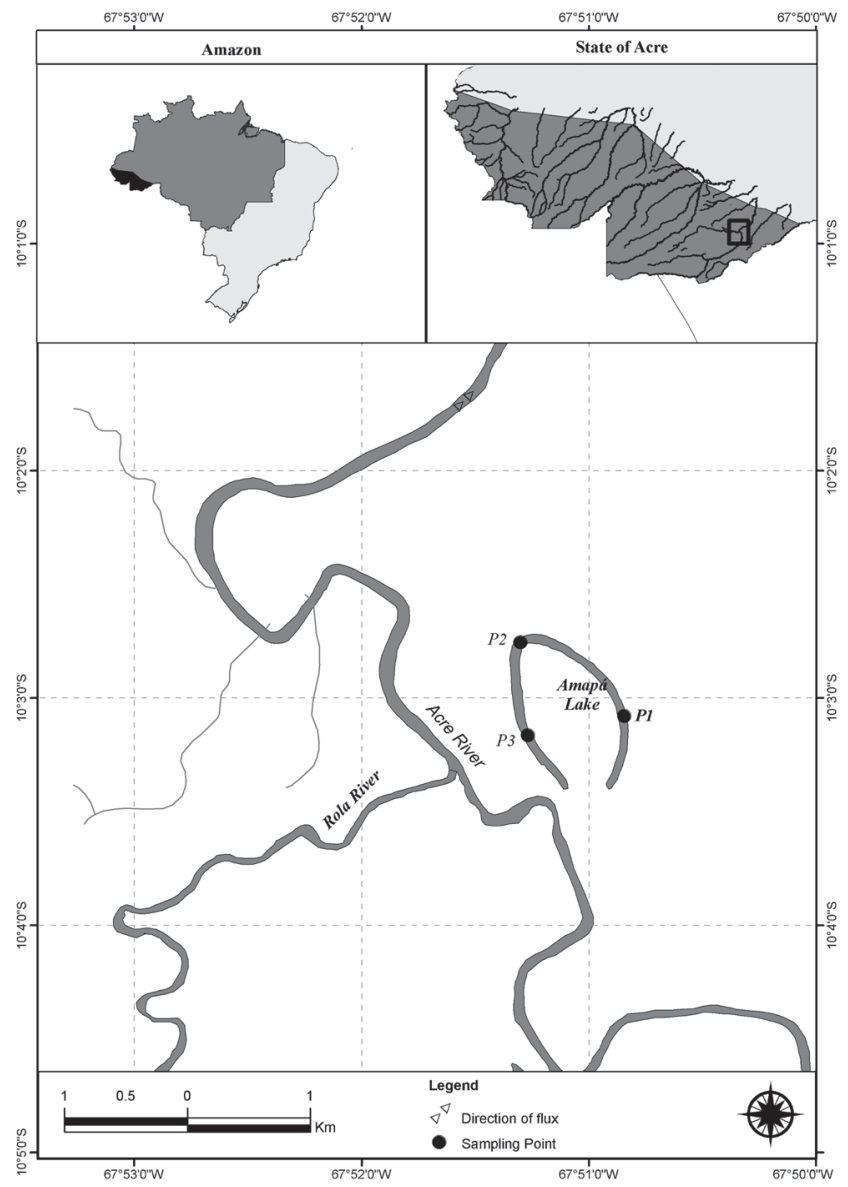

Fig. 1. Location of Lake Amapá and sampling points P1, P2, and P3.

by the Civil Defense agency of the state of Acre. The water levels in Amazon floodplain lakes are regulated by inflow from the rivers, and their depth may vary several meters during five to seven months a year, according to the hydrological regime of the rivers supplying the water (Adis \& Junk, 2002).

Fish collections. Sampling was carried out monthly from October 2008 through September 2009, at three points on Lake Amapá, using a set of four nets of different mesh sizes $(1.5,2.5,3.5$, and $4.0 \mathrm{~cm}$ between consecutive knots) and $40 \mathrm{~m}$ long, at each sampling point. Nets were installed for a $24-\mathrm{h}$ period and were checked at 19:00, 01:00, 07:00, and 13:00 hs. All fish collected were identified, measured, weighed, and eviscerated, and their stomachs were removed and preserved in $4 \%$ formalin. Voucher specimens were deposited in the Coleção Ictiológica do Núcleo de Pesquisas em Limnologia, Ictiologia e Aquicultura of the Universidade Estadual de Maringá (Nupelia-UEM) under number NUP 9114.

Diet analysis. The diet of T. curtus was evaluated by three methods: (1) frequency of occurrence, which is the number of times that a prey occurs in relation to the total number of 
stomachs analyzed, expressed as a percentage; (2) numerical frequency, which is obtained by counting the number of prey items of each food category in the stomachs, expressed as a percentage; and (3) the point method, which was adapted so that the contribution of the food items was estimated from the area of coverage of the item on the Sedgwick-Rafter chamber or graph paper, and the volume of each item corresponds to the proportional score for the coverage area. The points method was only used to obtain the volume of food items (expressed as a percentage), whose values were used to calculate the IRI (Hynes, 1950; Hyslop, 1980). The results of these methods were combined in the Index of Relative Importance (IRI, Pinkas et al., 1971), calculated by the formula: $\mathrm{IRI}=(\% \mathrm{~N}+\% \mathrm{P}) \% \mathrm{~F} * 100$, where: $\mathrm{N}=$ numerical frequency, $\mathrm{P}=$ percentage of points, and $\mathrm{F}=$ frequency of occurrence.

Temporal variations (pre-flooding, flooding and postflooding) in the diet of $T$. curtus were summarized by an ordination technique, Detrended Correspondence Analysis o (DCA - Hill \& Gauch, 1980), applied to the data matrix for the $\operatorname{diet}$ (244 samples and 16 items; lines and columns, respectively). The input matrix summarized in the DCA contained the point's value of each food item. As some food items presented high values, we conducted a square root transformation to minimize their effect on the ordination. In addition, we opted to run the DCA algorithm giving less weigh to rare food items, to also remove their effect on the ordination (for more details, see Palmer, 1993). The food items that most influenced the ordination in the diet between the sampling periods were determined from their Pearson correlation with the principal DCA matrix, using the program PC-ORD (McCune \& Mefford, 1999). To evaluate the temporal differences in the diet, we tested the scores of the samples controlling the periods resulting from the DCA. The DCA scores did not conform to the assumptions of normality and homogeneity, and therefore differences in the diet were tested according to the Kruskal-Wallis non-parametric test (Zar, 1996). When the differences were significant, the $a$ posteriori test (multiple comparisons of mean ranks for all groups) was used to indicate which periods differed. The significance level adopted for all analyses was $\mathrm{p}<0.05$.

\section{Results}

Hydrological regime. The water depth in Lake Amapá varied seasonally, influenced particularly by changes in the level of the Acre River during the flood period (January to June 2009). In the dry period, the lake's water level varied little. During the 2008-2009 hydrological cycle, three distinct periods were considered: (i) pre-flooding (October through December 2008) - the period when the water level in the lake remained relatively stable; (ii) flooding (January through June 2009) the period beginning when the Acre River water invaded the lake until the lake again became isolated from the main river channel; and (iii) post-flooding (July through September 2009) - the period from when the lake was isolated until the water level stabilized (Fig. 2).

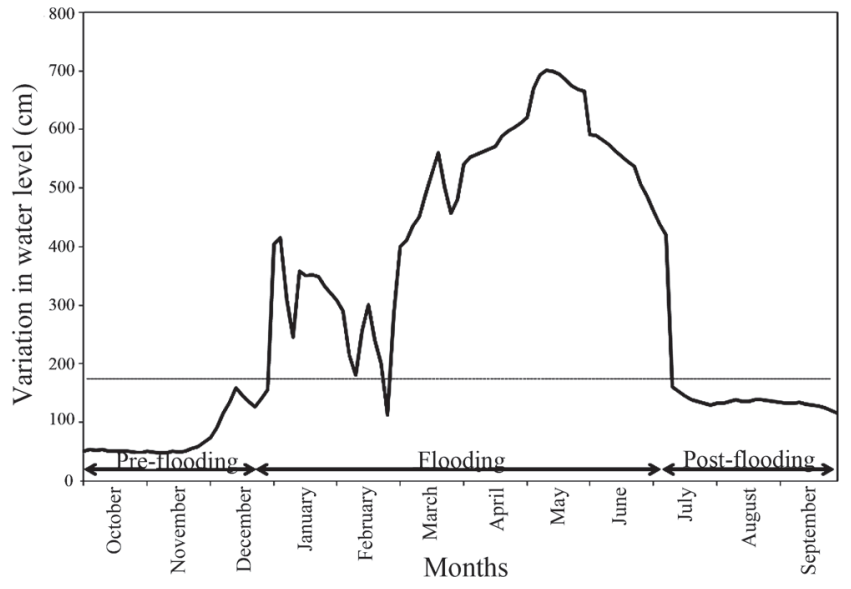

Fig. 2. Variation in river level (measured every three days) during the hydrological cycle from 2008 to 2009 in Lake Amapá. Gray line shows the threshold level for flooding from the Acre River. Main periods of pre-flooding, flooding, and postflooding are indicated at the base of the graph.

Temporal variation in diet. A total of 244 stomachs were analyzed to characterize the feeding habits of T. curtus. Its diet was composed essentially of insects of different orders and of microcrustaceans (Table 1). In the pre-flooding period, the principal food resource was Ostracoda (62\%), represented only by Physocypria schubarti (Farkas, 1958), and followed by Cladocera, which comprised $22 \%$ of the diet. In this period, Chaoboridae larvae and Algae were items of minor importance, representing $8.6 \%$ and $7.4 \%$ of the diet, respectively. In the flooding period, Chaoboridae larvae (44.3\%), and terrestrial insects (fragments) (33.7\%) comprised approximately $80 \%$ of

Table 1. Values of the Index of Relative Importance (\%IRI) of food items in the diet of Triportheus curtus, in three periods of the hydrological cycle. $\mathrm{N}=$ number of stomachs analyzed. Values of IRI $<0.01$ are indicated by an asterisk.

\begin{tabular}{llccc}
\hline Items & Food resource & $\begin{array}{c}\text { Pre- } \\
\text { flooding }\end{array}$ & Flooding & $\begin{array}{c}\text { Post- } \\
\text { flooding }\end{array}$ \\
\hline Ostracoda & Autochthonous & 61.87 & 17.99 & 4.21 \\
Cladocera & Autochthonous & 21.85 & 2.08 & 15.31 \\
Chaoboridae & Autochthonous & 8.62 & 44.31 & 79.5 \\
Terrestrial insects & Allochthonous & 0.27 & 33.7 & 0.88 \\
(fragments) & Autochthonous & 0.01 & - & $*$ \\
Ephemeroptera & Autochthonous & - & - & $*$ \\
Coleoptera & Allochthonous & $*$ & - & $*$ \\
Hymenoptera & Autochthonous & $*$ & 1.17 & 0.06 \\
Hemiptera & Autochthonous & $*$ & - & - \\
Plecoptera & Autochthonous & - & - & $*$ \\
Trichoptera & Autochthonous & $*$ & - & - \\
Rotifera & Autochthonous & $*$ & 0.31 & 0.03 \\
Copepoda & Autochthonous & $*$ & - & - \\
Hydracarina & Autochthonous & 7.36 & 0.44 & $*$ \\
Algae & Allochthonous & - & - & $*$ \\
Plant & Autochthonous & 0.01 & - & - \\
Scales & & 169 & 13 & 62 \\
N & & & &
\end{tabular}


the diet. Ostracoda was also prominent in this period, comprising $18 \%$ of the diet. In the Post-flooding, fish consumed mainly Chaoboridae larvae, responsible for approximately $80 \%$ of the diet, while Cladocera comprised $15.3 \%$ (Table 1).

The results of the data ordination for T. curtus's diet indicated important temporal separations. The variation revealed by this ordination showed that on axis 1 most of the samples from the flooding and post-flooding were positioned on the right side of the graph, whereas the samples from the pre-flooding occupied the left side of the graph (Fig. 3). Along DCA axis 1 (eigenvalue $=0.43$ ), the most highly correlated food items were Ostracoda $(r=-0.53)$, Algae $(r=-0.52)$, and Cladocera $(\mathrm{r}=-0.51)$ negatively, and terrestrial insects (fragments) $(\mathrm{r}=0.62)$, positively. The food items that correlated with DCA axis 2 (eigenvalue $=0.19)$ were terrestrial insects (fragments) $(\mathrm{r}=0.52)$ positively, and Chaoboridae larvae $(\mathrm{r}=-0.71)$ negatively (Table 2).

Significant differences among the scores for the different periods were recorded for axis $1(\mathrm{df}=2, \mathrm{H}=91.05 ; \mathrm{p}=0.001)$. The $a$ posteriori test indicated that there were differences between the periods of pre-flooding and flooding $(p<0.01)$ and between the pre-flooding and post-flooding $(p<0.01)$. No difference was observed between the periods of flooding and post-flooding $(\mathrm{p}=1.0)$ (Fig. 4a). The differences can be explained due to greater consumption of Ostracoda and Cladocera during the pre-flooding periods, which had high correlation with the scores.

For axis 2 (Fig. 4b) $(\mathrm{df}=2, \mathrm{H}=63.62 ; \mathrm{p}<0.001)$, we observed differences between the pre-flooding and post-flooding $(\mathrm{p}<$ 0.01 ), and between the flooding and post-flooding $(\mathrm{p}<0.01)$, however no differences were seen between the pre-flooding and flooding $(p=0.287)$. In the post-flooding, the proportion of Chaoboridae in the diet increased sharply in relation to the preflooding and flooding. This difference may be due to the high negative correlation of this item with the sample scores.

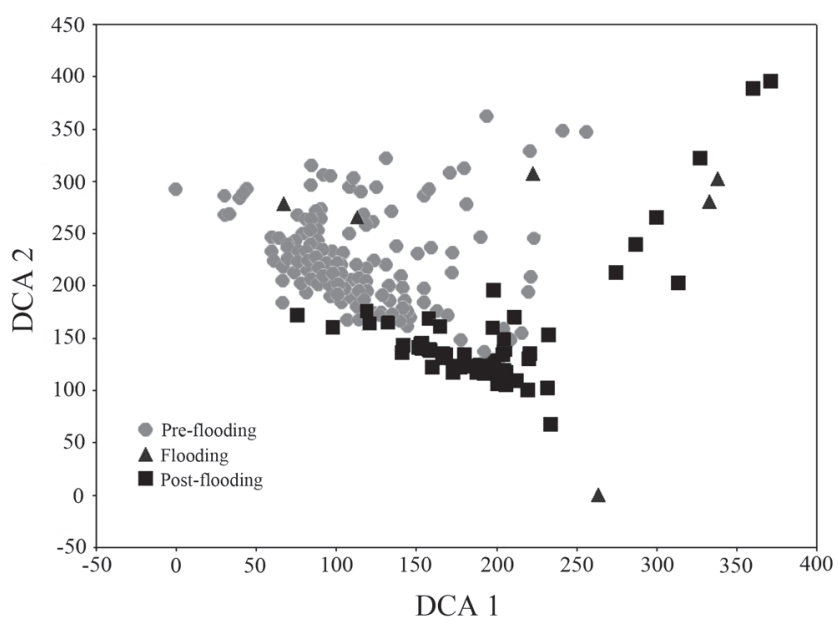

Fig. 3. Scores derived from Detrended Correspondence Analysis (DCA), considering the seasonal ordination of Triportheus curtus in the periods of the hydrological cycle of Lake Amapá.

\section{Discussion}

As a result of fluctuations in water level, the diet of $T$. curtus varied significantly among the stages of the hydrological cycle. Ostracoda was the most consumed item in the pre-flooding, Chaoboridae larvae, and terrestrial insects (fragments) in the flooding, and Chaoboridae larvae and Cladocera in the postflooding. In lakes of Amazon floodplain and Pantanal the food spectra of species of Triportheus ranged from omnivore to insectivore (Catella \& Petrere Jr, 1998; Yamamoto et al., 2004).

According to Martens et al. (2008), Ostracoda are very common in the majority of continental waters, where they are abundant in benthic communities. In this study, these invertebrates were ingested by $T$. curtus in the largest amounts in the pre-flooding, although the IRI indicated that the ingestion of Ostracoda decreased in flooding and post-flooding, this item continued frequent in the stomachs, with about $40 \%$ and $60 \%$ respectively (Fig. 5). Although T. curtus is a pelagic species (Malabarba, 2004), and the majority of Ostracoda is benthic or associated with macrophytes (Higuti et al., 2007), the explanation for the high consumption of these organisms may be related to the fact that some species of Ostracoda migrate upwards and swim in the water column. These include species of the genus Physocypria (Delorme, 2001) the only member of Ostracoda consumed by $T$. curtus.

The high consumption of terrestrial insects by the fish reflects the importance of allochthonous material as a food resource for ichthyofauna (Vidotto-Magnoni \& Carvalho, 2009). The input of allochthonous material into tropical aquatic ecosystems during the flood season can explain the presence of terrestrial insects (fragments) in the diet of T. curtus during the flooding period, when strong rains and winds cause the insects to fall into these waterbodies. Also, insects, especially Hymenoptera, become easy prey for pelagic fish such as species of Triportheus when the riverine forests are flooded, because

Table 2. Values of Pearson's correlation (r) among food items of Triportheus curtus in Lake Amapá, on DCA axes 1 and 2. Values are listed in ascending order.

\begin{tabular}{lcclcc}
\hline & DCA 1 & & & \multicolumn{2}{c}{ DCA 2 } \\
\cline { 1 - 2 } \cline { 5 - 5 } \cline { 5 - 5 } Items & $\mathrm{R}$ & & Items & $\mathrm{R}$ \\
\hline Ostracoda & -0.53 & & Chaoboridae & -0.71 \\
Cladocera & -0.52 & & Cladocera & -0.23 \\
Scales & -0.51 & & Hemiptera & -0.18 \\
Plecoptera & -0.09 & & Copepoda & -0.15 \\
Rotifera & -0.03 & & Coleoptera & -0.09 \\
Ephemeroptera & -0.01 & & Trichoptera & -0.07 \\
Hydracarina & 0.02 & & Plant & -0.06 \\
Copepoda & 0.02 & & Rotifera & -0.01 \\
Plant & 0.03 & & Scales & 0.04 \\
Coleoptera & 0.05 & & Plecoptera & 0.06 \\
Trichoptera & 0.05 & & Ostracoda & 0.08 \\
Hymenoptera & 0.05 & & Ephemeroptera & 0.11 \\
Hemiptera & 0.17 & & Hydracarina & 0.12 \\
Chaoboridae & 0.22 & & Hymenoptera & 0.15 \\
Terrestrial insects & 0.24 & & Algae & 0.19 \\
(fragments) & 0.62 & & Terrestrial insects & (fragments) & 0.52 \\
\hline
\end{tabular}



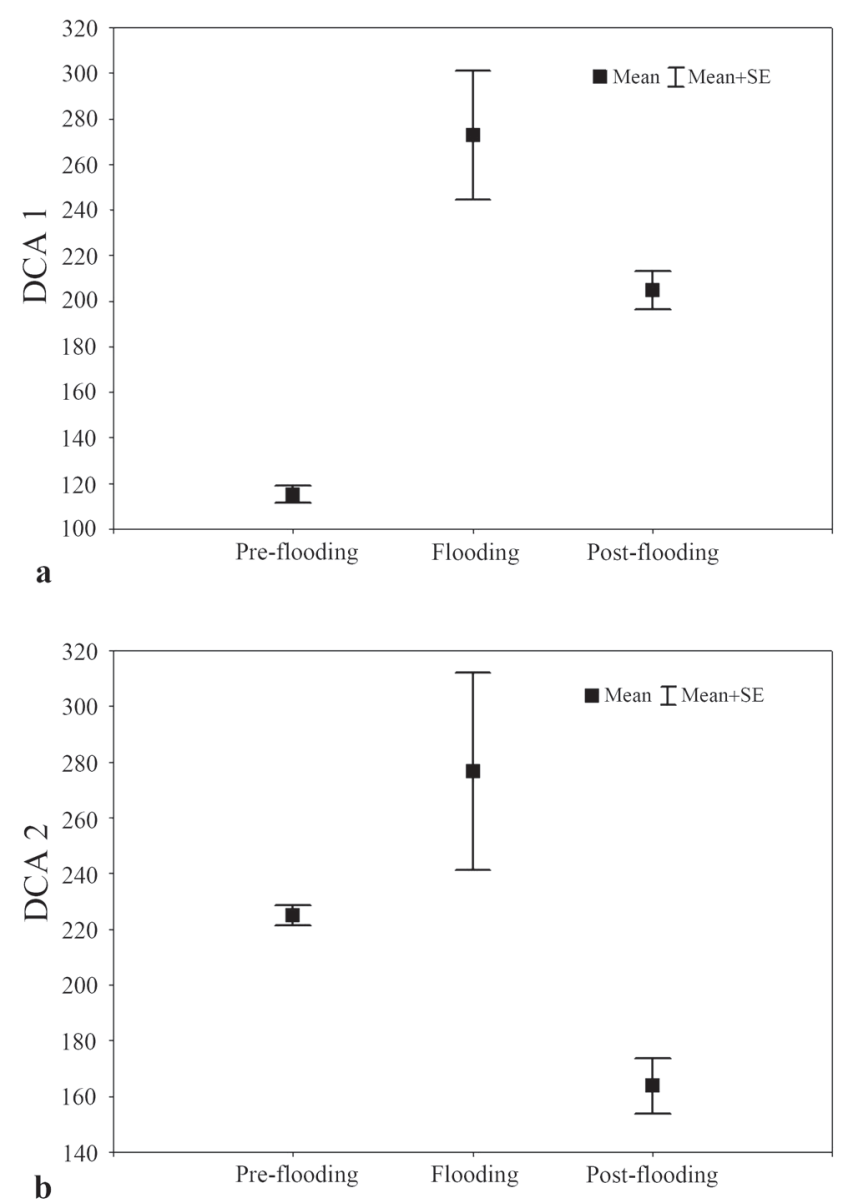

Fig. 4. Mean values for scores ( \pm standard error) for axes 1 (a) and 2 (b) of the detrended correspondence analysis (DCA), in the different sampling periods.

the fish are adapted to exploit these areas (Yamamoto et al., 2004). Arboreal and terrestrial forms of insects in the Amazon forests fall into the water during the flood period, where they constitute an important resource for the fish (Goulding et al., 1988). This source of food is transitory but sustains many species of fishes, mainly the trophic opportunists (Hahn \& Fugi, 2007). The pelagic habit of T. curtus facilitates the consumption of these insects, which float on the water surface.

Chaoboridae was important in the diet of T. curtus, especially during periods of post-flooding and flooding. These Diptera are planktonic in the larval stage, and are found in the majority of lacustrine environments (Esteves, 1988), where they carry out vertical migrations to avoid fish predation (Luoto \& Nevalainen, 2009). In isolated lakes, the high organic-matter content in the bottom sediments promotes the dominance of certain groups of invertebrates, especially species of Chaoborus (Ezcurra de Drago et al., 2007), which may have led T. curtus to feed intensively on this resource. Another factor that may have influenced the predation on these Diptera larvae is that in the tropics, the reproduction of Chaoboridae is continuous, and consequently the predation pressure would also be continuous throughout the year, varying with the seasonal fluctuations in density of Chaoboridae (Arcifa, 2000), as observed by high abundance (flooding and post-flooding) in stomachs of $T$. curtus.

Cladocera was the second most important food resource of T. curtus when the water level of Lake Amapá was low (preflooding and post-flooding). Fish are important predators of zooplankton in floodplain lakes, where the zooplankton community is highly abundant and species-rich, due to the great heterogeneity of habitats created by the seasonal changes in water level (Russo \& Hahn, 2006). Keppeler \& Hardy (2004) studying the zooplankton of Lake Amapá, noted that there was a greater abundance of Cladocera (species of the genus Moina and Diaphanosoma) predominantly in the low water period, corroborating the results found in this study where T. curtus was also fed by these planktonic Cladocera.

Triportheus curtus showed seasonal variations in the composition of their diet, and is considered a carnivorous species with a preference for Ostracods in pre-flooding and Chaoboridae larvae in flooding and post-flooding. The species can be considered opportunistic, given the inclusion of different food items according to abundance in all three phases of the hydrological cycle. The predominance of opportunists in tropical riverine environments reflects the spatial and temporal oscillations in the relative abundance of food items (Abelha et al., 2001). The trophic plasticity of opportunist species may result from the necessity of utilizing a variety of food items in adverse conditions, an important factor in their survival in these environments (Teixeira et al., 2005).

In conclusion, the utilization of food resources by $T$. curtus was variable, changing with alterations in the availability of resources, as influenced by the flooding. The population of $T$. curtus proved to be opportunistic, changing its diet in the course of the hydrological cycle. These are characteristics of the species of Amazon fishes that show wide feeding plasticity.

\section{Acknowledgements}

The authors thank the Fundo de Desenvolvimento Científico e Tecnológico do Acre-FDCT by financial support, the REUNI by grant awarded, and CAPES (PROCAD Novas Fronteiras) by the opportunity of training in statistics to the first author. We are grateful to Luiz Carlos Gomes (UEM) for help with statistical analyses, to Carla Pavanelli (UEM) for help on fish identification, to the technician Willians Monteiro Aiache and to the team of the Laboratório de Ictiologia e Ecologia Aquática-ICTIOLAB for help in the fieldwork.

\section{Literature Cited}

Abelha, M. C. F., A. A. Agostinho \& E. Goulart. 2001. Plasticidade trófica em peixes de água doce. Acta Scientiarum, 23: 425-434.

Adis, J. \& W. J. Junk. 2002. Terrestrial invertebrates inhabiting lowland river oodplains of Central Amazonia and Central Europe: a review. Freshwater Biology, 47: 711-731. 
Amaral, B. D. 2005. Fisheries and fishing effort at the indigenous reserves Ashaninka/Kaxinawá, river Breu, Brazil/Peru. Acta Amazonica, 35: 133-144.

Arcifa, M. S. 2000. Feeding habits of Chaoboridae larvae in a tropical Brazilian reservoir. Revista Brasileira de Biologia, 60: 591-597.

Batista, V. S. \& M. Petrere Jr. 2003. Characterization of the commercial fish production landed at Manaus, Amazonas state, Brazil. Acta Amazonica, 33: 53-66.

Catella, A. C. \& M. Petrere Jr. 1998. Body-shaped and food habits of fish from Baía da Onça, a pantanal floodplain lake, Brazil. Verhandlungen Internationale Vereinigung für Theoretische und Angewandte Limnologie, 26: 2203-2208.

Daga, V. S., T. M. Gogola, P. V. Sanches, G. Baumgartner, D. Baumgartner, P. A. Piana, E. A. Gubiani \& R. L. Delariva. 2009. Fish larvae assemblages in two floodplain lakes with different degrees of connection to the Paraná River, Brazil. Neotropical Ichthyology, 7: 429-438.

Delorme, L. D. 2001. Ostracoda. Pp. 811-848. In: Thorp, J. H. \& A. P. Covich. (Eds.). Ecology and Classification of North American Freshwater Invertebrates. San Diego, Academic Press, 1056p.

Doria, C. R. C. \& L. J. Queiroz. 2008. A pesca comercial das sardinhas (Triportheus spp.) desembarcadas no mercado pesqueiro de Porto Velho, Rondônia (1990-2004): Produção pesqueira e perfil geral. Biotemas, 21: 99-106.

Esteves, F. A. 1988. Fundamentos de Limnologia. Rio de Janeiro, Interciência, $574 \mathrm{p}$.

Ezcurra de Drago, I., M. Marchese \& L. Montalto. 2007. Benthic Invertebrates. Pp. 251-275. In: Iriondo, M., J. Paggi \& J. Parma. (Eds.). The Middle Paraná River. Limnology of a Subtropical Wetland. New York, Springer, 382p.

Galina, A. B. \& N. S. Hahn. 2003. Comparação da dieta de duas espécies de Triportheus (Characidae, Triportheinae), em trechos do reservatório de Manso e lagoas do rio Cuiabá, Estado do Mato Grasso. Acta Scientiarum, 25: 345-352.

Goulding, M. 1980. The Fishes and the Forest. Explorations in Amazonian Natural History. Los Angeles, University of California Press, 280p.

Goulding, M., L. M. Carvalho \& E. G. Ferreira. 1988. Rio Negro, Rich Life in Poor Water. The Hague, SPB Academic Publishing, 200p.

Hahn, N. S. \& R. Fugi. 2007. Alimentação de peixes em reservatórios brasileiros: alterações e conseqüências nos estágios iniciais do represamento. Oecologia Brasiliensis, 11: 469-480.

Hamilton, S. K. \& W. M. Lewis Jr. 1987. Causes of seasonality in the chemistry of a lake on the Orinoco River floodplain, Venezuela. Limnology and Oceanography, 32: 1277-1290.

Higuti, J., L. F. M. Velho, F. A. Lansac-Tôha \& K. Martens. 2007. Pleuston communities are buffered from regional ood Floodings: the example of ostracods in the Paraná River foodplain, Brazil. Freshwater Biology, 52: 1930-1943.

Hill, M. O. \& H. G. Gauch. 1980. Detrended correspondence analysis, an improved ordination technique. Vegetatio, 42: 47-58.

Hynes, H. B. N. 1950. The food of fresh-water sticklebacks (Gasterosteus aculeatus and Pygosteus pungitius) with a review of methods used in studies of the food of fishes. Journal of Animal Ecology, 19: 36-58.

Hyslop, E. J. 1980. Stomach contents analysis review of methods and their applications. Journal of Fish Biology, 17: 411-429.

Junk, W. J. 1980. Áreas inundáveis - um desafio para limnologia. Acta Amazônica, 10: 775-795.

Keppeler, E. C. \& E. R. Hardy. 2004. Vertical distribution of zooplankton in the water column of Lago Amapá, Rio Branco, Acre, Brazil. Revista Brasileira de Zoologia, 21: 169-177.
Luoto, T. P. \& E. L. Nevalainen. 2009. Larval chaoborid mandibles in surface sediments of small shallow lakes in Finland: implications for palaeolimnology. Hydrobiologia, 631: 185-195.

Luz-Agostinho, K. D. G., A. A. Agostinho, L. C. Gomes, H. F. JúlioJr \& R. Fugi. 2009. Effects of flooding regime on the feeding activity and body condition of piscivorous fish in the Upper Paraná River floodplain. Brazilian Journal of Biology, 69: 481490.

Luz, S. C. S., A. C. A. El-Deir, E. J. França \& W. Severi. 2009. Estrutura da assembléia de peixes de uma lagoa marginal desconectada do rio, no submédio Rio São Francisco, Pernambuco. Biota Neotropica, 9: 117-129.

Malabarba, M. C. S. L. 2004. Revision of the Neotropical genus Triportheus Cope, 1872 (Characiformes: Characidae). Neotropical Ichthyology, 2: 167-204.

Marçal-Simabuku, M. A. \& A. C. Peret. 2002. Alimentação de peixes (Osteichthyes, Characiformes) em duas lagoas de uma planície de inundação brasileira da bacia do rio Paraná. Interciência, 27: 299-306.

McCune, B. \& M. J. Mefford. 1999. Multivariate analysis of ecological data, version 5.0. Gleneden Beach, Oregon, MjM Software Design, 47p.

Martens, K., I. Schön, C. Meisch \& D. J. Horne. 2008. Global diversity of ostracods (Ostracoda, Crustacea) in freshwater. Hydrobiologia, 595: 185-193.

Neiff, J. J., A. P. Neiff \& M. B. C. Verón. 2009. The role of vegetated areas on fish assemblage of the Paraná River floodplain: effects of different hydrological conditions. Neotropical Ichthyology, 7: 39-48.

Palmer, M. W. 1993. Putting things in even better order: the advantages of canonical correspondence analysis. Ecology, 74: 2215-2230.

Pinkas, L., M. S. Oliphant \& I. L. K. Iverson. 1971. Food habits of albacore, bluefin tuna, and bonito in California waters. California Department of Fish and Game, Fish Bulletin, 152, 105p.

Russo, M. R. \& N. S. Hahn. 2006. Importance of zooplankton in the diet of a small fish in lagoons of the upper Paraná River floodplain, Brazil. Acta Limnologica Brasiliensia, 18: 357-366.

Sousa, R. G. C. \& C. E. C. Freitas. 2008. The influence of flood Flooding on fish communities of floodplain canals in the Middle Solimões River, Brazil. Neotropical Ichthyology, 6: 249-255.

Teixeira, T. P., B. C. T. Pinto, B. F. Terra, E. O. Estiliano, D. Gracia \& F. G. Araújo. 2005. Diversidade das assembléias de peixes nas quatro unidades geográficas do rio Paraíba do Sul. Iheringia, Série Zoologia, 95: 347-357.

Thomaz, S. M., L. M. Bini \& R. L. Bozelli. 2007. Floods increase similarity among aquatic habitats in River-floodplain systems. Hydrobiologia, 579: 1-13.

Vidotto-Magnoni, A. P. \& E. D. Carvalho. 2009. Aquatic insects as the main food resource of fish the community in a Neotropical reservoir. Neotropical Ichthyology, 7: 701-708.

Winemiller, K. O., S. Tarim, D. Shormann \& J. B. Cotner. 2000. Fish assemblage structure in relation to environmental variation among Brazos River oxbow lakes. Transactions of the American Fisheries Society, 129: 451-468.

Yamamoto, K. C., M. G. M. Soares \& C. E. C. Freitas. 2004. Alimentação de Triportheus angulatus (Spix \& Agassiz, 1829) no lago Camaleão, Manaus, AM, Brasil. Acta Amazonica, 34: 653-659.

Zar, J. H. 1996. Biostatistical Analysis. New Jersey, Prentice Hall, $620 \mathrm{p}$.

Submitted January 10, 2011

Accepted May 10, 2011

Published September 16, 2011 